\title{
Correlation between the major components of Phyllanthus amarus and Phyllanthus urinaria and their inhibitory effects on phagocytic activity of human neutrophils
}

\author{
Ibrahim Jantan ${ }^{*}$, Menaga llangkovan $^{\dagger}$, Yuandani ${ }^{\dagger}$ and Hazni Falina Mohamad
}

\begin{abstract}
Background: Recently, we have highlighted the immunomodulatory activity of the standardized extracts of Phyllanthus amarus and P. urinaria. The present study was carried out to correlate between the prevalent constituents of the herbs and their inhibitory effects on phagocytic activity of human neutrophils.

Methods: The compounds, gallic acid, ellagic acid, corilagin, geraniin, phyllanthin and hypophyllanthin were identified and quantitatively analyzed in the extracts of Phyllanthus amarus and P. urinaria obtained from Malaysia and Indonesia by using a validated reversed phase high performance liquid chromatography (RP-HPLC) method. The standardized extracts and the pure compounds were evaluated for their effects on chemotaxis, $\beta 2$ integrin (CD18) expression, phagocytosis and chemiluminescence of human phagocytes. Chemotactic activity was assessed using the Boyden chamber technique, inhibition of CD18 expression and phagocytic ability were tested with the aid of flow cytometry, while effect on the respiratory burst was investigated using a luminol-based chemiluminescence assay.

Results: All plant extracts strongly inhibited migration of the phagocytes with the Malaysian P. amarus depicting the highest inhibitory activity. Amongst the compounds tested, geraniin demonstrated the strongest inhibitory activity on chemotaxis of polymorphonuclear leukocytes (PMNs) and monocytes with $I_{50}$ values of 1.09 and $1.69 \mu \mathrm{M}$, respectively, which were lower than that of ibuprofen. All plant extracts and pure compounds exhibited high inhibitory activity on the oxidative burst of zymosan and PMA stimulated leukocytes. Geraniin and corilagin exhibited exceptionally strong inhibition on the reactive oxygen species (ROS) activity with $\mathrm{IC}_{50}$ values lower than aspirin. The plant extracts exhibited moderate inhibition of $E$. coli uptake by monocytes but weak effect on PMNs. Of all the compounds, phyllanthin at $50 \mathrm{\mu g} / \mathrm{mL}$ exhibited the highest engulfment inhibitory activity with percentage of phagocytizing cells of 14.2 and 27.1\% for PMNs and monocytes, respectively. All plants and compounds tested possessed weak effect on CD18 expression on leukocytes except for hypophyllanthin and phyllanthin which exhibited significant inhibitory effect.

Conclusion: The strong inhibition of the extracts on the phagocytic activity of neutrophils was due to the presence of their major constituents especially geraniin, corilagin, phyllanthin and hypophllanthin which were able to modulate the innate response of phagocytes at different steps.
\end{abstract}

Keywords: Phyllanthus amarus, Phyllanthus urinaria, Immunomodulatory effects, Phagocytosis, Phyllanthin, Hypophyllanthin, Geraniin, Corilagin

\footnotetext{
* Correspondence: profibj@gmail.com

${ }^{\dagger}$ Equal contributors

Drug and Herbal Research Center, Faculty of Pharmacy, Universiti

Kebangsaan Malaysia, Jalan Raja Muda Abdul Aziz, Kuala Lumpur 50300,

Malaysia
}

\section{Ciomed Central}

(C) 2014 Jantan et al.; licensee BioMed Central Ltd. This is an Open Access article distributed under the terms of the Creative Commons Attribution License (http://creativecommons.org/licenses/by/4.0), which permits unrestricted use, distribution, and reproduction in any medium, provided the original work is properly credited. The Creative Commons Public Domain Dedication waiver (http://creativecommons.org/publicdomain/zero/1.0/) applies to the data made available in this article, unless otherwise stated. 


\section{Background}

Immune system is designed to protect the host by destroying and eliminating the invading pathogen. It requires the timely interplay of a number of different types of cells within a specific microenvironment to maintain the immune homeostasis [1]. Human immune response is divided into two main categories which include innate immunity, initiated by phagocytosis of pathogens by phagocytic cells and this orchestrates the adaptive immune system [2-4]. The two types of circulating phagocytes, neutrophils and monocytes, are the main contributors to innate immune system. In response to invasive bacterial infection, circulating phagocytes perform a number of specific activities, including migration of phagocyte cells to the site of infection, adherence to blood vessel walls, transmigration into injured tissues, phagocytosis, degranulation, and reactive oxygen species production [5]. Chemotaxis is referred to the migration of phagocytes to the site of infection upon the activation by either endogeneous chemoattractants such as interleukin 8 (IL-8), leukotriene B4 (LTB4), platelet activating factor (PAF) or exogeneous chemoattractants such as formyl methionyl-leucyl-phenylalanine (fMLP) derived from bacterial products [6-8].

Rapid regulation of adhesive interactions between phagocytes and vessel wall are essential in proper recruitment of leukocytes and defensive against invasive pathogens. Interactions between leukocytes and endothelial cells are largely mediated by selectin family of receptors and integrins. CD11/CD18 antigen complex have been reported as an important group of adhesion molecule involved in granulocyte interaction with other cells as well as with antigens [9]. The interaction between phagocyte and ligand at the site of infection leads to a sequential event known as oxidative burst to kill the microbial intruders $[10,11]$. Oxidative burst involves the increased oxygen consumption and generation of highly reactive superoxide anion radical $\left(\mathrm{O}_{2}^{-}\right)$and hydroxyl radicals $\left(\mathrm{OH}^{-}\right)$and hydrogen peroxides $\left(\mathrm{H}_{2} \mathrm{O}_{2}\right)$. Despite its host defense, exaggerated function of human phagocyte can also be involved in cell and tissue damage associated with severe inflammatory reactions and autoimmune disorders [12]. Thus, modulation of phagocytic activity through different pathways plays an essential role in keeping them in a highly prepared state for any threat it may encounter [13].

In this context, the utilization of medicinal plants and their active components as immunomodulators to substitute conventional therapy has gained momentum in recent years [14-18]. However, little is known about the immunomodulatory activity of Malaysian medicinal plants. The plants belonging to the genus Phyllanthus (family: Euphorbiaceae) are widely distributed in tropical and subtropical countries which have long been used in folk medicine for the treatment of liver, asthma, kidney and bladder problems and diabetes [19]. Besides, the anti-viral properties of some Phyllanthus species, mainly against hepatitis $\mathrm{B}$ have extended the medicinal properties of these plants in traditional medicine [20]. Amongst all the species of Phyllanthus, $P$. amarus has gained a remarkable interest in past few decades due to its variety of organic compounds of medicinal importance including flavonoids, ellagitannins, alkaloids, polyphenols, lignans and triterpenes $[21,22]$. $P$. urinaria is yet another species of Phyllanthus which has been reported to possess various biological activities including anti-tumor, anti-angiogenic, anti-inflammation, anti-hypertensive, anti-microbial and anti-viral activities [23-25]. The biosynthesis of secondary metabolites of these plants has been reported to vary among plants grown in different environmental factors [26,27]. Our previous studies on Phyllanthus amarus and P. urinaria for their phagocytic properties have revealed that the standardized methanol extracts of these plants have the potential to exhibit strong immunomodulatory effect on human neutrophils [28]. In many previous studies, Phyllanthus species have been reported for their wide spectrum of pharmacological activities [29,30]. However, investigations to correlate the chemical constituents of the plants with their biological and pharmacological effects were seldom reported. The present study was carried out to investigate the effects of the major components of the $80 \%$ ethanol extracts of $P$. amarus and $P$. urinaria on phagocytic activity of human neutrophils in an effort to correlate the effectiveness of the plants with those of their components.

\section{Methods}

\section{Chemicals and reagents}

Serum opsonized zymosan A (Saccharomyces cerevisiae suspensions and serum), lipopolysaccharide (LPS), Fluorescein isothiocyanate (FITC)-labelled opsonized Escherichia coli, luminol (3-aminophthalhydrazide), phosphate buffer saline tablet (PBS), Hanks Balance Salt Solutions (HBSS), Ficoll, Hanks Balance Salt Solution (HBSS), Nformyl-methionylleucyl-phenylalanine (fMLP), Tryphan blue, MTT reagent, aspirin (purity 99\%), ibuprofen (purity 99\%), phorbol 12-myristate 13-acetate (PMA),and dimethylsulfoxide (DMSO) were purchased from Sigma (St Louis, MO, USA). Fetal calf serum was obtained from PAA Laboratories (USA). CD18-FITC (anti-LFA-1ß), isotypematched Immunoglobulin-FITC (IgG1-FITC) and FACS lysing solution were obtained from Becton Dickinson, USA. Chemiluminescence measurements were carried out on a Luminoskan Ascent luminometer (Thermo Scientific, UK). fMLP was stored as a stock solution of $10^{-8} \mathrm{M}$ in DMSO at $-80^{\circ} \mathrm{C}$ and diluted in Hanks solution, prior to assay. Phagocytic kit was purchased from Oregen Pharmagen, USA. Haematoxylin and xylene for staining were obtained from BDH, UK. A Boyden 48-well chamber with a $3 \mu \mathrm{m}$ 
and $5 \mu \mathrm{m}$ polycarbonate membrane filter separating the upper and lower compartments was purchased from Neuro Probe (Cabin John, MD, USA). Phyllanthin and hypophyllanthin (isolated based on method described in previous study with purity $>98 \%$ ) [28]. Whereas gallic acid, ellagic acid, corilagin and geraniin (purity >98\%) were purchased from ChromaDex (CA, USA). Methanol HPLC grade, acetonitrile HPLC grade, and, trifluoroacetic acid AR grade were obtained from E-Merck. Phagotest kit was obtained from Glycotope Technology, Germany. The flow cytometer BDFACS Canto II equipped with $488 \mathrm{~nm}$ argon-ion laser was used. $\mathrm{A} \mathrm{CO}_{2}$ incubator (Shell Lab, USA), light microscope, and high-performance liquid chromatograph (Waters 2998) (Leitz Watzler, Germany) were also used in this assay.

\section{Plant materials and preparation of extracts}

The whole plants of Phyllanthus amarus and P. urinaria were obtained from Marang, Kuala Terengganu, Malaysia and Tanjung Anom, Northern Sumatra, Indonesia between February and June 2012. The plants were identified by Dr Abdul Latif Mohamad of Faculty of Science and Technology, Universiti Kebangsaan Malaysia (UKM), and voucher specimens ( $P$. amarus UKMB 30078 and $P$. urinaria UKMB 30077) were deposited at the Herbarium of UKM, Bangi, Malaysia. No specific permissions were required for the collection of plant samples from Marang, Kuala Terengganu, Malaysia and Tanjung Anom, Northern Sumatra, Indonesia. The collection of plant samples did not involve endangered or protected species and the study was carried out at the Drug and Herbal Research Centre, Faculty of Pharmacy, UKM. The aerial parts of P. amarus and $P$. urinaria (100 g each) were ground and extracted with $80 \% \mathrm{EtOH}(3 \times 3 \mathrm{~L})$ at room temperature for $72 \mathrm{~h}$ and filtered through Whatman No.1 filter paper (Whatman, England). The filtrate was collected and excess solvent was evaporated under reduced pressure using rotary evaporator at $55^{\circ} \mathrm{C}$ to dryness to obtain dark yellowish green ethanol extract of $P$. amarus (Malaysia, $10.8 \mathrm{~g}, 10.8 \%$; Indonesia, $10.1 \mathrm{~g}, 10.1 \%$ ) and P.urinaria (Malaysia, $9.68 \mathrm{~g}$, 9.7\%; Indonesia, 7.48 g, 7.5\%).

\section{Quantitative determination of the major components of plant extracts by HPLC}

One hundred mg each of the $80 \%$ ethanol extracts of Phyllanthus amarus and P. urinaria was dissolved into $10 \mathrm{~mL}$ of $\mathrm{MeOH}$ and $1 \mathrm{mg}$ each of the reference standards (gallic acid, ellagic acid, corilagin, geraniin, phyllanthin and hypophyllanthin) in $1 \mathrm{~mL}$ of $\mathrm{MeOH}$ were ultra sonicated at ambient temperature for $10 \mathrm{~min}$ and filtered through $0.45 \mu \mathrm{m}$ Millipore Millex PTFE membrane (Maidstone, Kent, UK). Phyllanthin and hypophyllanthin (isolated based on method described in previous study with purity $>98 \%$ ). Whereas gallic acid, ellagic acid, corilagin and geraniin (purity $>98 \%$ ) were purchased from ChromaDex (CA, USA). The diluted solutions of the extracts and the reference standards were analyzed separately by HPLC using the following conditions: Column: Reverse Phase, C-18 column (250 mm $\times 4.6 \mathrm{~mm}$ i.d., $5 \mu \mathrm{m}$, Xbridge, Waters, Ireland), and detector: PDA (Waters 2998) of wavelength ranging from 205 to $270 \mathrm{~nm}$. For the analysis of the extracts and standard solutions of phenolic compounds (gallic acid, ellagic acid, corilagin, geraniin) gradient elution was used with acetonitrile 99.99\% (solvent A) and orthophosphoric acid $0.2 \%$ (solvent B) as mobile phase at a flow rate of $0.6 \mathrm{~mL} / \mathrm{min}$ with the following procedure; $5-70 \%$ A (0 to $15 \mathrm{~min}$ ), 70 to $95 \%$ A (15 to $30 \mathrm{~min}$ ) and pump A had been hold at $95 \%$ for $20 \mathrm{~min}$. Corilagin was used as external standard for the identification and quantification of the phenolic compounds. Identification and quantification of the lignans (phyllanthin and hypophyllanthin) were carried out based on the chromatographic condition as described in our previous study [28]. The identification of each compound was carried out by comparing the retention times and UV-Vis spectra of the peaks with those obtained by the injection of the standards. The calibration curves were plotted with five concentrations each of the standard solution of compounds versus the areas under the peaks. The standard curves equations obtained from each compounds were used to quantify the compounds in the extracts.

\section{Validation procedures for HPLC analysis}

Validation of the HPLC method was carried out by determination of linearity, precision, limits of quantification (LOQ) and detection (LOD). LOD and LOQ were calculated based on the standard deviation $(\sigma)$ of the responses of the lowest concentration in calibration curve of six runs $(n=5)$ and the slope of the calibration curves of external standards, respectively. Correlation coefficient $\left(R^{2}\right)$ was calculated from the calibration curves and linearity was evaluated by linear calibration analysis. Intra-assay and inter-assay validation were performed to determine the precision of the method. Separately, one concentration of extracts $(10 \mathrm{mg} / \mathrm{mL})$ and reference compounds $(1 \mathrm{mg} / \mathrm{mL})$ were injected three times in one day and on three different days. LOD and LOQ were calculated from the RSD and slope $(S)$ of the calibration curves using equations: $\mathrm{LOD}=3.3 \times(\mathrm{RSD} / S)$ and $\mathrm{LOQ}=10 \times$ $(\mathrm{RSD} / S)$.

\section{Isolation of human polymorphonuclear leukocytes and monocytes}

Ten $\mathrm{mL}$ of fresh venous blood was obtained in heparincontaining tubes by aseptic vein puncture from healthy human volunteers who fulfilled the following inclusion criteria: non-smoker, fasted overnight and did not take 
any medicine or supplements. The whole blood was then aliquot into falcon tubes and equal amount of dextran and PBS were added and the mixture was left for $45 \mathrm{~min}$ at room temperature $\left(26^{\circ} \mathrm{C} \pm 2\right)$ for sedimentation. The PMN isolation was performed by using a modified method of $\mathrm{Oh}$ et al. [31]. The supernatant was centrifuged by Ficoll-gradient separation and then washed twice with cold distilled water for the lysis of red blood cells. PMN cells sedimented at the bottom of the tubes. Whereas the isolation of monocytes was performed by using a modified method of Gmelig et al. [32]. Briefly, $10 \mathrm{~mL}$ of venous blood from healthy individual was diluted (1:1) with physiological saline before being applied to the gradient. Diluted blood was then carefully layered on lympho prep and centrifuged at $400 \times \mathrm{g}$ for $20 \mathrm{~min}$. After centrifugation the mononuclear cells formed a distinct band at the medium interface and was slowly removed using pasteur pipette without removing the upper layer. The fraction was diluted with PBS and centrifuged at $250 \times \mathrm{g}$ for $10 \mathrm{~min}$ for the purification of cells. These cells were then suspended in PBS and cell suspension were counted using haemocytometer and number of cells were adjusted to a final concentration of $1 \times 10^{6}$ cells $/ \mathrm{mL}$. The use of human blood was approved by the Human Ethical Committee, Faculty of Medicine, Universiti Kebangsaan Malaysia (approval number FF/ 2012/Ibrahim/23-May/432-May 2012-August 2013). Written informed consent was obtained from individual human volunteer participating in this study prior to blood collection.

\section{Cell viability}

Cytotoxicity of $P$. amarus and $P$. urinaria extracts and standard compounds on monocytes was measured by using MTT [33] while viability of PMNs was determined by the standard trypan blue exclusion method [34]. For the MTT assay, one hundred $\mu \mathrm{L}$ sample of five different concentrations $(6.25-100 \mu \mathrm{g} / \mathrm{mL})$ of the samples were filled into a 96 well round bottom microplate containing $100 \mu \mathrm{L}$ cells suspension in RPMI $164010 \%$ FCS. The plates were incubated for $24 \mathrm{~h}$ at $37^{\circ} \mathrm{C}$ and $5 \% \mathrm{CO}_{2}$. Twenty $\mu$ l of MTT reagent $(1 \mathrm{mg} / \mathrm{mL})$ was added into each well and incubated for $4 \mathrm{~h}$ at $37^{\circ} \mathrm{C}$ and $5 \% \mathrm{CO}_{2}$. The supernatant removed and the formazan produced by cells in each well was dissolved in DMSO and the optical densities (OD) were measured by ELISA readers at $570 \mathrm{~nm}$ [33]. The standard trypan blue exclusion assay was carried out by incubating neutrophils $\left(1 \times 10^{6} / \mathrm{mL}\right)$ with 6.25 or $100 \mu \mathrm{g} / \mathrm{mL}$ of samples and 3.125 to $100 \mu \mathrm{g} / \mathrm{mL}$ of pure compounds in triplicate at $37^{\circ} \mathrm{C}$ for $2 \mathrm{~h}$. Cell death was indicated by the blue dye uptake and percentage viability was calculated from the total cell counts [34].

\section{Chemiluminescence assay}

Chemiluminescence assays were carried out as described by Jantan et al. [34]. Briefly, $25 \mu \mathrm{L}$ diluted whole blood or $25 \mu \mathrm{L}$ monocytes (adjusted to $1 \times 10^{6}$ ) or $25 \mu \mathrm{L}$ PMN (adjusted to $1 \times 10^{6}$ ) suspended in $\mathrm{HBSS}^{++}$were incubated with $25 \mu \mathrm{L}$ of sample with different concentrations ranging from 6.25 to $100 \mu \mathrm{g} / \mathrm{mL}$ in 96 well flat bottom microplate. Inducement of the cells was with $25 \mu \mathrm{L}$ of opsonized zymosan or PMA. This was followed by the addition of $25 \mu \mathrm{L}$ of luminol $\left(1 \times 10^{5} \mathrm{M}\right)$ and the final volume of each well was adjusted to $200 \mu \mathrm{L}$ with $\mathrm{HBSS}^{++}$. The microplate was then incubated at $37^{\circ} \mathrm{C}$ for $50 \mathrm{~min}$ in the thermostatically controlled chamber of the luminometer. The control wells contained 0.6\% DMSO, $\mathrm{HBSS}^{++}$, luminol without sample and aspirin, a non-steroidal antiinflammatory drug (NSAID), was used as a standard drug. The luminometer results were monitored as chemiluminescence RLU (reading per luminometer unit) with peak and total integral values set with repeated scans at $30 \mathrm{~s}$ intervals and $1 \mathrm{~s}$ points measuring time.

\section{Chemotaxis assay}

The assay was performed using a modified 48-well Boyden chamber with formyl-methionylleucyl-phenylalanine (fMLP) a bacterial peptide as a chemoattractant, as previously described by Jantan et al. [34]. Aliquots of $25 \mu \mathrm{L}$ of fMLP $(10-8 \mathrm{M})$ were added to the wells in lower chamber. Serial dilutions of $5 \mu \mathrm{L}$ of each extract $(6.25-100 \mu \mathrm{g} / \mathrm{mL})$ were added to the upper chamber containing $45 \mu \mathrm{L}$ PMNs $\left(1 \times 10^{6}\right.$ cells per $\left.\mathrm{mL}\right)$ or $45 \mu \mathrm{L}$ monocytes $\left(1 \times 10^{6}\right.$ cells per $\mathrm{mL}$ ) suspended in $\mathrm{HBSS}^{++}$. The final concentrations of the samples in the mixture were adjusted to $10,5,2.5$, 1.25 , and $0.625 \mu \mathrm{g} / \mathrm{mL}$. The control wells contained the chemoattractant buffer $\mathrm{HBSS}^{++}$and DMSO (1:1). The cells were then incubated for one $\mathrm{h}$ at $37^{\circ} \mathrm{C}$ in a $\mathrm{CO}_{2}$ incubator. Haematoxylin and xylene were used to fix and stain migrated cells which had adhered to the distal part of the filters. The cell migration distance was measured by using a light microscope. Ibuprofen was used as a standard drug.

\section{Phagocytic assay}

The assay was performed according to the protocol given by the manufacturer (ORPEGEN Pharma). Briefly, $100 \mu \mathrm{L}$ heparinized peripheral whole blood was incubated with $20 \mu \mathrm{L}$ pre-cooled FITC-labelled opsonized $E$. coli and $20 \mu \mathrm{L}$ of test samples (extracts: 6.25 and 100 $\mu \mathrm{g} / \mathrm{mL}$; pure compounds: 3.125 and $50 \mu \mathrm{g} / \mathrm{mL}$ ) in a closed shake water bath at $37^{\circ} \mathrm{C}$ for $10 \mathrm{~min}$. Positive control was without test sample under similar condition while the negative control was without test sample and remained on ice. At the end of the incubation time icecold quenching solution was added to the mixture to quench phagocytosis. Subsequently lysing solution was 
added for lysis of red blood cells and fixation of leukocytes. Cells were then washed twice and resuspended in $200 \mu \mathrm{L}$ of DNA staining solution for cytometric discrimination of bacteria during leukocyte analysis. The phagocytic ability of neutrophils and monocytes was determined by flow cytometry using the blue-green excitation light (488 $\mathrm{nm}$ argon-ion laser). Live populations were gated by the software program in the scatter diagram (FCS versus SSC). Phagocytic activity was determined as the percentage of phagocytizing neutrophils and monocytes.

\section{CD18 integrin expression of leukocytes}

The CD18 integrin expression assay was performed using a modified method of Mazzone et al. [35]. Peripheral blood was obtained from heparinized venous blood of normal voluntary donors. Aliquots $(100 \mu \mathrm{L})$ of whole blood were then incubated in the presence or absence of samples with different concentrations at $37^{\circ} \mathrm{C}$ for $30 \mathrm{~min}$. Thereafter, cells were stimulated with LPS $(0.25 \mu \mathrm{g} / \mathrm{mL})$ for $90 \mathrm{~min}$ at $37^{\circ} \mathrm{C}$ in a $\mathrm{CO}_{2}$ incubator. Then, all the tubes were simultaneously transferred into ice bath to stop the reaction. Subsequently $10 \mu \mathrm{L}$ of CD18-FITC or Immunoglobulin G-FITC (negative control) was added into the mixture. All the tubes were incubated for $60 \mathrm{~min}$ on ice. FACS lysing solution was added into each tube and incubated in dark for $20 \mathrm{~min}$ for the lysis of red blood cells. The tubes were centrifuged at $250 \mathrm{~g}$ for $5 \mathrm{~min}$ at $4^{\circ} \mathrm{C}$ and supernatant was removed from the tubes and cells were washed with PBS (3x). $500 \mu$ of PBS was added into each tube and expression of adhesion molecules was determined by flow cytometry and compared with adhesion molecule expression of untreated cells. Neutrophils and monocytes were discriminated in terms of forward and side scatter. Forward scatter is correlated to cell size, whereas side scatter is related to cell granularity. The specific mean fluorescence intensity for cells stained by each antibody is reported as the ratio of the CD18 to that of the negative control antibody. For each sample, 10,000 cells were analyzed.

\section{Statistical analysis}

All the data are presented as means \pm standard error median (SEM) from triplicate experiments and were analyzed using statistical package for social sciences (SPSS) software version 20.0. The $\mathrm{IC}_{50}$ values were calculated using Graph PAD Prism 6 Analysis software. Data were analyzed using a oneway analysis of variance (ANOVA)for multiple comparisons. $P<0.05$ was considered to be statistically significant.

\section{Results and discussion}

Quantitative determination of the major components of the $80 \%$ ethanol extracts of Phyllanthus amarus and P. urinaria.

The chromatograms of the reversed-phase HPLC column of the $80 \%$ ethanol extracts of $P$. amarus and $P$. urinaria showed four major peaks of gallic acid, geraniin, corilagin and ellargic acid, corresponding to retention times at 8.172, 23.694, 26.436 and $33.529 \mathrm{~min}$, respectively (Figure 1). The quantitative determination of the lignans, phyllanthin and hypophyllanthin, their precision, specificity, quantitation limit and detection limit have been reported in our previous study [28]. The identification of gallic acid (GA), ellagic acid (EA), corilagin (Cor) and geraniin (Ger) was carried out by comparing with the retention times of standard solutions of these compounds. The phenolic compounds identified in the extracts were quantified by using corilagin as external standard. The amounts of the major compounds are shown in Table 1. The calibration curve plotted for standard solution of corilagin over the concentration range of $62.5-500 \mu \mathrm{g} / \mathrm{mL}$ showed a correlation coefficient $\left(r^{2}\right)$ of

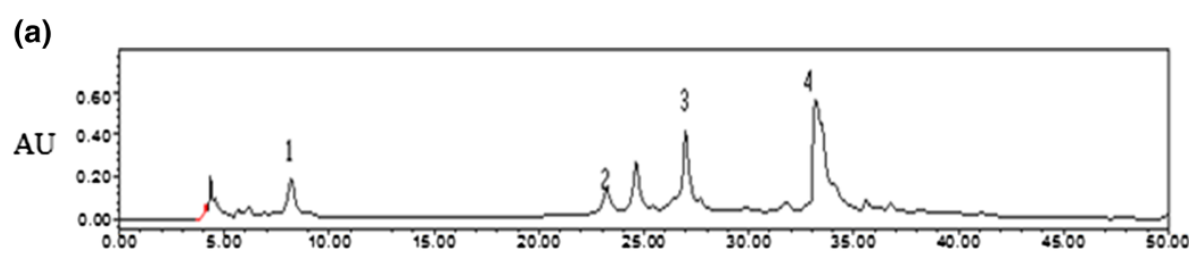

(b)

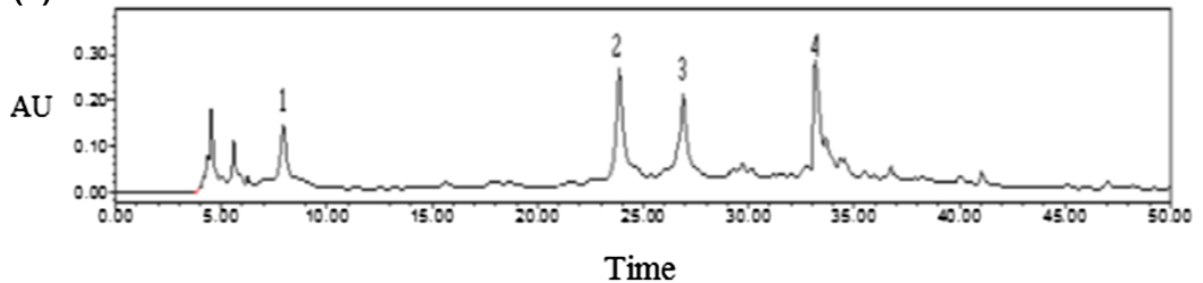

Figure 1 Representative HPLC chromatograms of (a) P. amarus (Mal), (b) $P$. urinaria (Mal) for identification and quantification of gallic acid (1) at RT $8.172 \mathrm{~min}$, geraniin (2) at RT $23.694 \mathrm{~min}$,corilagin (3) at RT $26.436 \mathrm{~min}$, ellagic acid (4) at RT $33.529 \mathrm{~min}$ at the wavelength of $270 \mathrm{~nm}$. See Table 2 for legends. 
Table 1 Amount of major compounds found in Phyllanthus amarus and P.urinaria $(\mu \mathrm{g} / \mathrm{mL})$ obtained from HPLC quantification analysis

\begin{tabular}{|c|c|c|c|c|c|c|}
\hline Species & Phyllanthin & Hypophyllanthin & Gallic acid & Ellagic acid & Corilagin & Geraniin \\
\hline PA (Mal) & 103.50 & 114.00 & 163.30 & 601.29 & 313.41 & 170.49 \\
\hline PA (Ind) & 79.10 & 121.85 & 142.92 & 219.06 & 413.42 & 234.52 \\
\hline PU (Mal) & 16.80 & 19.50 & 103.48 & 231.34 & 159.37 & 173.17 \\
\hline PU (Ind) & 1.9 & 3.91 & 93.05 & 346.12 & 379.23 & 199.50 \\
\hline
\end{tabular}

PA: Phyllanthus amarus, PU: Phyllanthus urinaria, Mal: Malaysia, Ind: Indonesia.

0.9958. The reproducibility of the results was confirmed by results of relative standard deviation (RSD \%) of mean area under peak $1.81 \%$ and mean of retention time values $0.93 \%$ for interday assay, whereas the \% RSD values for intra-assay precision of peak area and retention time were 3.68 and $1.09 \%$. Limit of detection (LOD) and limit of quantification (LOQ) of corilagin were found to be 1.86 and $5.65 \mathrm{ng} / \mathrm{mL}$, respectively.

Quantitative determination of the major compounds by HPLC indicated that $P$. amarus from Malaysia contained the highest amounts of phyllanthin $(103.5 \mu \mathrm{g} / \mathrm{mL})$, gallic acid $(163.3 \mu \mathrm{g} / \mathrm{mL})$ and ellagic acid $(601.29 \mu \mathrm{g} / \mathrm{mL})$, while $P$. amarus from Indonesia contained the highest amount of hypophyllantin $(121.85 \mu \mathrm{g} / \mathrm{mL})$. Corilagin $(379.23 \mu \mathrm{g} / \mathrm{mL})$ was found in highest concentration in the extract of $P$. urinaria from Indonesia. The variations in the amounts of the major compounds in the plants of similar species collected from different geographical locations were partly due to the different environmental factors related to altitude and genetic adaptation of the populations growing at different altitudes to specific environment [26].

\section{Chemotaxis assay}

The cell viability test was carried out using trypan blue and MTT assays for PMNs and monocytes, respectively, to evaluate the cytotoxicity of extracts of Phyllanthus amarus and P. urinaria as well as the standard compounds. The extracts and the standard compounds at concentrations ranging from 6.25 to $100 \mu \mathrm{g} / \mathrm{mL}$ showed more than $95 \%$ of cell viability except for phyllanthin and hypophyllanthin which possessed cell viability $>95 \%$ at concentrations ranging from 0.3125 to $5 \mu \mathrm{g} / \mathrm{mL}$. The results indicate that leucocytes were viable in the reaction mixtures in the presence of the extracts and the compounds which were non toxic and could potentially modulate the cellular immune response. The inhibitory activities of the extracts and standard compounds at the serial dilutions of 10 to $0.625 \mu \mathrm{g} /$ $\mathrm{mL}$, on the migration of PMNs towards the chemoattractant (fMLP), were determined and their percentage inhibitions (\%) were shown in Figure 2. Chemoattractant buffer (DMSO and HBSS, 1:1 ratio) was used as a control and ibuprofen was used as a

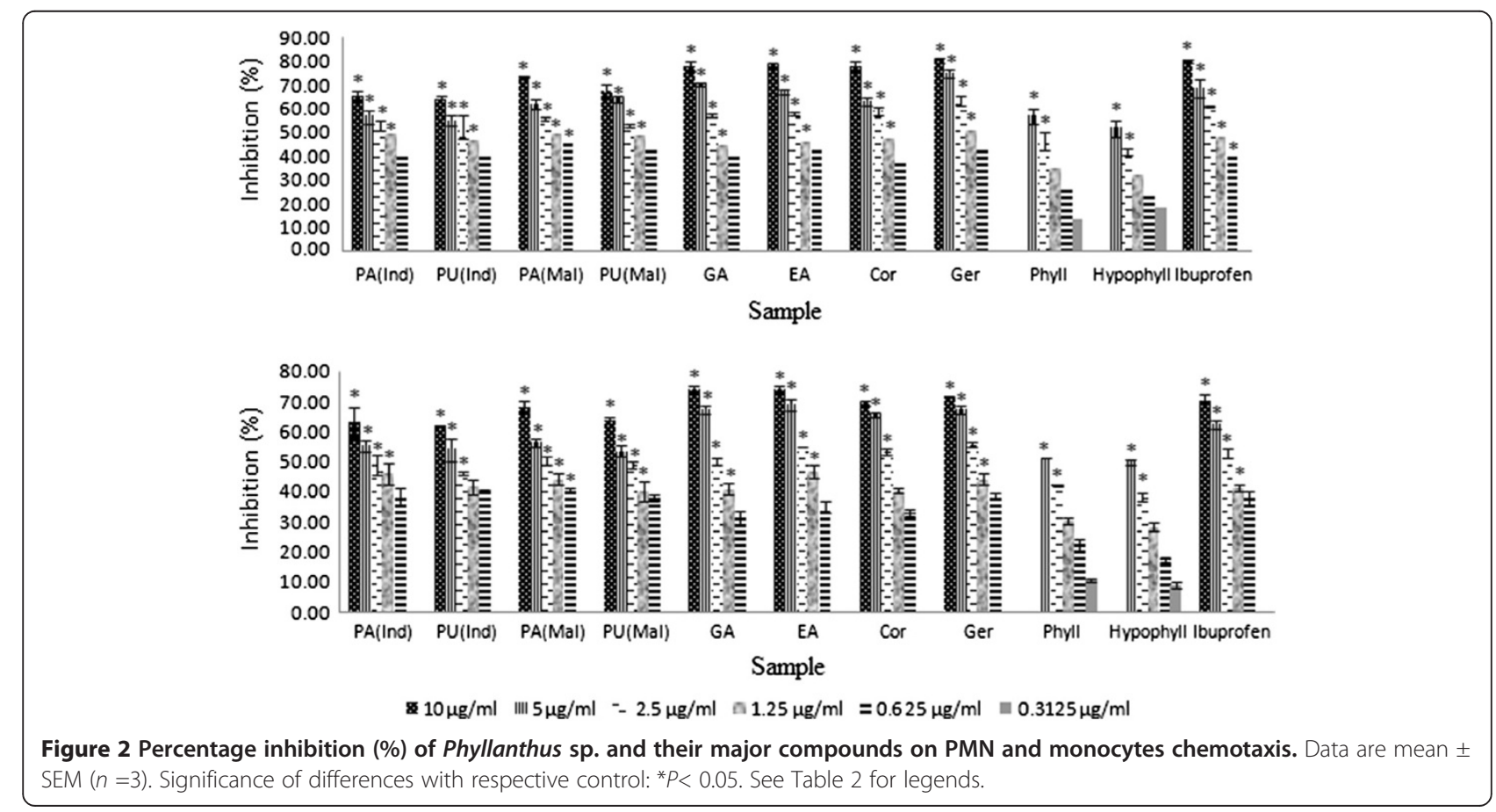


positive control. Chemotactic activity of the extracts of $P$. amarus and $P$. urinaria from both Malaysia and Indonesia on human phagocytes in response to $\mathrm{N}$ formylmethionyl-leucylphenylalanine (fMLP) was suppressed in a concentration-dependent manner. Amongst the extracts, $P$. amarus from Malaysia depicted the most potent inhibitory activity on PMNs and monocytes migrations with $\mathrm{IC}_{50}$ values of 1.22 and $1.44 \mu \mathrm{g} / \mathrm{mL}$, respectively (Table 2). Amongst the major compounds identified in $P$. amarus and $P$. urinaria, geraniin, corilagin and ellagic acid demonstrated lower $\mathrm{IC}_{50}$ values than that of ibuprofen, with geraniin being the strongest inhibitor with $\mathrm{IC}_{50}$ values of 1.09 and $1.69 \mu \mathrm{M}$ against PMNs and monocytes, respectively. Ibuprofen was used in previous study as a positive control and it was found to be the most effective NSAIDS in blocking the migration of PMNs [36]. There was an inversed correlation between the amount of phenolic compounds and the chemotactic activity of fMLP stimulated phagocytic cells. This is in congruity with previous studies which indicated that the presence of galloyl moeties in phenolics contribute to the inhibition of migration of fMLP stimulated migration of phagocytes by potent inhibition of activity of enzyme elastase $[37,38]$.

\section{Phagocytic assay}

The ability of PMNs and monocytes to phagocytize opsonized $E$. coli was evaluated by phagotest kit and analyzed by flow cytometry. The $E$ coli was opsonized with immunoglobulin and complement of pooled sera. The phagocytic activity was calculated based on the percentage of $E$. coli ingestion by phagocytes. The complement opsonized microbes were recognized by complement surface receptors on leukocytes. The Fab portion of the antibody binds to the antigen, whereas the constant part of the antibody $(\mathrm{Fc})$ binds to an Fc receptor on the phagocyte, facilitating phagocytosis [39]. The extracts of Phyllanthus amarus and P. urinaria at 100 and $6.25 \mu \mathrm{g} /$ $\mathrm{mL}$ exhibited moderate inhibition of $E$. coli uptake by monocytes but weak effect on neutrophils, as shown in Figure 3 and Table 3 . At $100 \mu \mathrm{g} / \mathrm{mL}$, all plant extracts showed moderate engulfment inhibitory activity with percentage of phagocytizing cells ranging from 53.70 to $66.68 \%$ for monocytes. The engulfment inhibitory activity at normal condition at $37^{\circ} \mathrm{C}$ was used as a positive control and normal condition at $0^{\circ} \mathrm{C}$ as negative control (Table 3). Except for phyllanthin and hypophyllanthin, all pure compounds did not show significant activity on the bacterial engulfment by human leukocytes.

Table 2 IC $_{50}$ values $(\mu \mathrm{g} / \mathrm{mL})$ of ROS inhibitory and chemotaxis activities of Phyllanthus amarus and $P$. urinaria and their major compounds on phagocytes (mean $\pm \mathrm{SEM}, n=3$ )

\begin{tabular}{|c|c|c|c|c|c|c|c|c|}
\hline \multirow[t]{3}{*}{ Sample } & \multirow{2}{*}{\multicolumn{2}{|c|}{$\begin{array}{c}\text { Chemotaxis } \\
\text { fMLP }\end{array}$}} & \multicolumn{6}{|c|}{ Chemiluminescence } \\
\hline & & & \multicolumn{3}{|c|}{ Zymosan } & \multicolumn{3}{|c|}{ PMA } \\
\hline & PMNs & MNCs & Whole Blood & PMNs & MNCs & Whole Blood & PMNs & MNCs \\
\hline PA (Mal) & $1.22 \pm 0.10$ & $1.44 \pm 0.80$ & $0.95 \pm 0.24$ & $0.58 \pm 1.80$ & $0.10 \pm 0.17$ & $1.24 \pm 0.98$ & $0.42 \pm 0.75$ & $0.56 \pm 0.30$ \\
\hline PA (Ind) & $1.84 \pm 0.01$ & $2.35 \pm 0.23$ & $8.14 \pm 1.71$ & $0.12 \pm 0.05$ & $2.19 \pm 2.55$ & $6.02 \pm 1.33$ & $1.34 \pm 0.59$ & $1.27 \pm 0.80$ \\
\hline PU (Mal) & $1.46 \pm 0.10$ & $2.84 \pm 0.30$ & $1.52 \pm 0.53$ & $1.00 \pm 1.21$ & $1.23 \pm 0.88$ & $1.98 \pm 1.09$ & $0.45 \pm 0.23$ & $0.26 \pm 0.12$ \\
\hline PU (Ind) & $2.21 \pm 0.90$ & $2.92 \pm 0.14$ & $9.74 \pm 1.09$ & $1.64 \pm 0.58$ & $0.36 \pm 0.29$ & $4.80 \pm 1.80$ & $1.34 \pm 1.18$ & $1.06 \pm 0.31$ \\
\hline GA & $\begin{array}{c}1.40 \pm 0.02 \\
(8.22 \pm 0.15)\end{array}$ & $\begin{array}{c}2.00 \pm 0.03 \\
(11.75 \pm 0.23)\end{array}$ & $\begin{array}{c}1.70 \pm 0.03 \\
(9.99 \pm 0.12)\end{array}$ & $\begin{array}{c}0.43 \pm 1.02 \\
(2.53 \pm 0.10)\end{array}$ & $\begin{array}{c}1.29 \pm 0.87 \\
(7.58 \pm 0.50)\end{array}$ & $\begin{array}{c}0.87 \pm 0.12 \\
(5.11 \pm 0.15)\end{array}$ & $\begin{array}{c}0.48 \pm 0.01 \\
(2.82 \pm 0.15)\end{array}$ & $\begin{array}{c}1.28 \pm 0.01 \\
(7.52 \pm 0.12)\end{array}$ \\
\hline EA & $\begin{array}{c}1.33 \pm 0.07 \\
(4.40 \pm 0.12)\end{array}$ & $\begin{array}{c}1.81 \pm 0.12 \\
(5.96 \pm 0.12)\end{array}$ & $\begin{array}{c}1.36 \pm 0.08 \\
(4.50 \pm 0.16)\end{array}$ & $\begin{array}{c}0.56 \pm 0.02 \\
(1.85 \pm 0.35)\end{array}$ & $\begin{array}{c}0.45 \pm 0.09 \\
(1.49 \pm 0.07)\end{array}$ & $\begin{array}{c}0.83 \pm 0.03 \\
(2.75 \pm 0.07)\end{array}$ & $\begin{array}{c}0.31 \pm 0.07 \\
(1.02 \pm 0.06)\end{array}$ & $\begin{array}{c}0.75 \pm 0.12 \\
(2.48 \pm 0.06)\end{array}$ \\
\hline Ger & $\begin{array}{c}1.04 \pm 0.12 \\
(1.09 \pm 0.23)\end{array}$ & $\begin{array}{c}1.61 \pm 0.14 \\
(1.69 \pm 0.05)\end{array}$ & $\begin{array}{c}0.34 \pm 0.30 \\
(0.36 \pm 0.12)\end{array}$ & $\begin{array}{c}0.18 \pm 0.07 \\
(0.18 \pm 0.02)\end{array}$ & $\begin{array}{c}0.37 \pm 0.41 \\
(0.38 \pm 0.07)\end{array}$ & $\begin{array}{c}0.19 \pm 0.12 \\
(0.21 \pm 0.01)\end{array}$ & $\begin{array}{c}0.12 \pm 0.04 \\
(0.13 \pm 0.01)\end{array}$ & $\begin{array}{c}0.36 \pm 0.61 \\
(0.38 \pm 0.12)\end{array}$ \\
\hline Cor & $\begin{array}{l}1.49 \pm 0.024 \\
(2.34 \pm 0.07)\end{array}$ & $\begin{array}{c}1.99 \pm 0.09 \\
(3.13 \pm 0.44)\end{array}$ & $\begin{array}{c}0.37 \pm 0.37 \\
(0.58 \pm 0.03)\end{array}$ & $\begin{array}{c}0.36 \pm 0.07 \\
(0.56 \pm 0.023)\end{array}$ & $\begin{array}{c}0.44 \pm 0.08 \\
(0.69 \pm 0.12)\end{array}$ & $\begin{array}{c}0.22 \pm 0.88 \\
(0.35 \pm 0.09)\end{array}$ & $\begin{array}{c}0.15 \pm 0.04 \\
(0.24 \pm 0.02)\end{array}$ & $\begin{array}{c}0.44 \pm 0.03 \\
(0.69 \pm 0.05)\end{array}$ \\
\hline Phyll & $\begin{array}{c}3.20 \pm 0.15 \\
(7.60 \pm 0.10)\end{array}$ & $\begin{array}{c}8.51 \pm 0.52 \\
(20.2 \pm 0.40)\end{array}$ & $\begin{array}{c}3.70 \pm 2.80 \\
(8.80 \pm 1.00)\end{array}$ & $\begin{array}{c}3.2 \pm 2.81 \\
(7.6 \pm 0.40)\end{array}$ & $\begin{array}{c}2.38 \pm 1.44 \\
(5.68 \pm 0.31)\end{array}$ & $\begin{array}{c}1.40 \pm 1.72 \\
(3.34 \pm 0.05)\end{array}$ & $\begin{array}{c}0.08 \pm 0.66 \\
(0.20 \pm 0.01)\end{array}$ & $\begin{array}{c}1.54 \pm 0.87 \\
(3.68 \pm 0.43)\end{array}$ \\
\hline Hypophyll & $\begin{array}{c}4.40 \pm 0.2 \\
(10.2 \pm 0.40)\end{array}$ & $\begin{array}{c}9.60 \pm 0.26 \\
(22.3 \pm 0.53)\end{array}$ & $\begin{array}{c}3.6 \pm 1.40 \\
(8.4 \pm 1.30)\end{array}$ & $\begin{array}{c}6.1 \pm 2.32 \\
(14.2 \pm 1.70)\end{array}$ & $\begin{array}{c}1.41 \pm 0.06 \\
(3.27 \pm 0.15)\end{array}$ & $\begin{array}{c}1.87 \pm 0.01 \\
(4.34 \pm 0.02)\end{array}$ & $\begin{array}{c}0.95 \pm 0.11 \\
(2.20 \pm 0.31)\end{array}$ & $\begin{array}{c}1.73 \pm 0.31 \\
(4.02 \pm 0.71)\end{array}$ \\
\hline Ibuprofen & $\begin{array}{c}1.40 \pm 0.10 \\
(6.60 \pm 0.10)\end{array}$ & $\begin{array}{c}1.98 \pm 0.05 \\
(9.57 \pm 0.23)\end{array}$ & & & & & & \\
\hline Aspirin & & & $\begin{array}{c}2.16 \pm 0.80 \\
(11.88 \pm 4.14)\end{array}$ & $\begin{array}{c}0.85 \pm 0.20 \\
(4.68 \pm 2.71)\end{array}$ & $\begin{array}{c}0.43 \pm 0.07 \\
(2.40 \pm 0.16)\end{array}$ & $\begin{array}{c}0.17 \pm 0.01 \\
(0.94 \pm 0.05)\end{array}$ & $\begin{array}{c}0.14 \pm 0.09 \\
(0.77 \pm 0.16)\end{array}$ & $\begin{array}{c}0.58 \pm 0.28 \\
(3.22 \pm 0.38)\end{array}$ \\
\hline
\end{tabular}

GA: Gallic acid, EA: Ellagic acid, Ger: Geraniin, Cor: Corilagin, Phyll: Phyllanthin, Hypophyll: Hypophyllanthin, PA: Phyllanthus amarus, PU: Phyllanthus urinaria, Mal: Malaysia, Ind: Indonesia.

$\mathrm{IC}_{50}$ values in $\mu \mathrm{M}$ are in parentheses. 


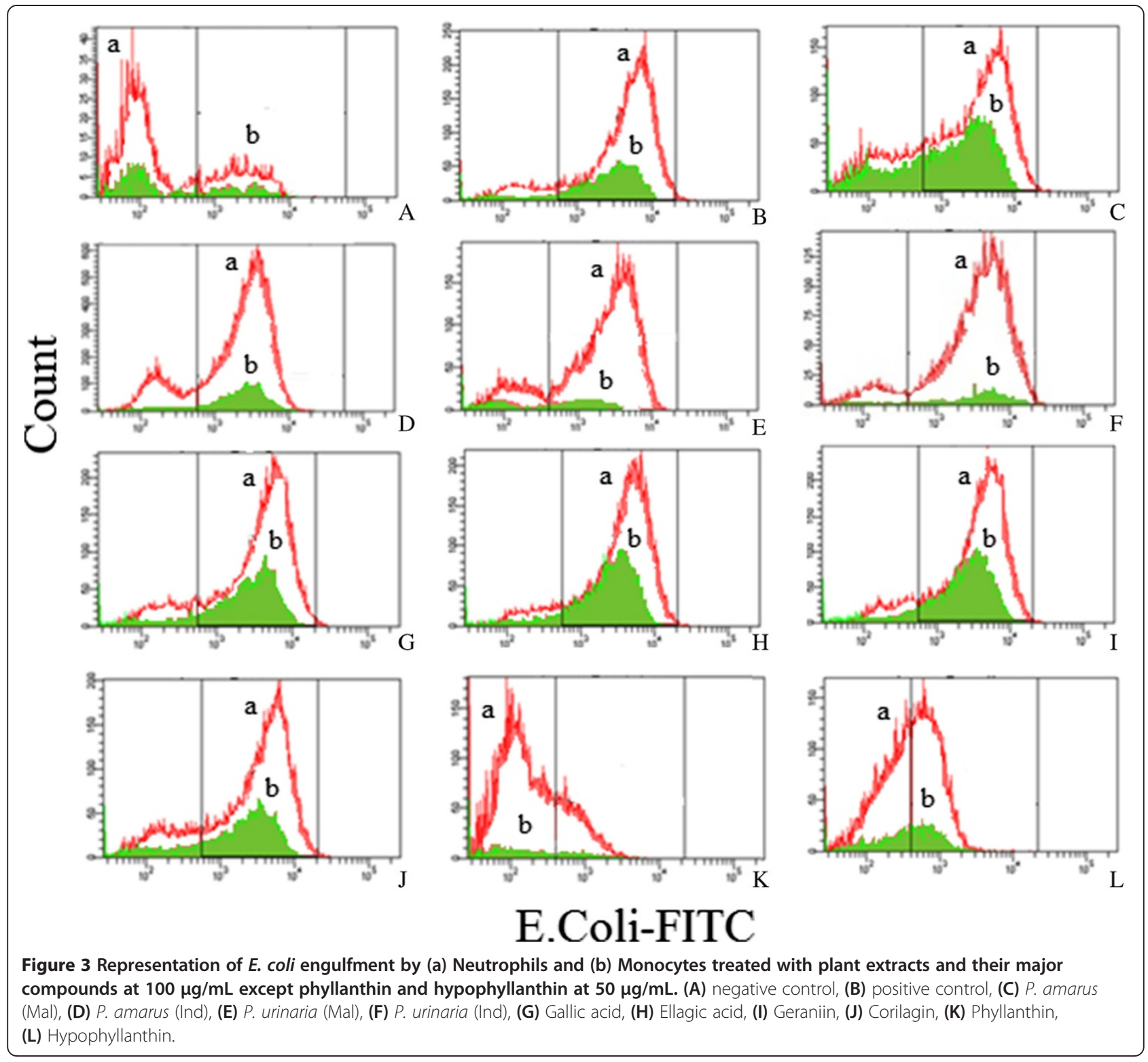

Phyllanthin at $50 \mu \mathrm{g} / \mathrm{mL}$ exhibited the highest engulfment inhibitory activity with percentage of phagocytizing cells of 14.2 and $27.1 \%$ for PMNs and monocytes, respectively. Phyllanthin might be the major contributor of phagocytic activity of the plant extracts. The results suggest that the moderate inhibitory of intake complement and opsonized E. coli of the compounds might be due to the inhibition of the complement surface receptors on leukocytes.

\section{Inhibition of CD18 expression assay}

The effects of the $P$. amarus and $P$. urinaria extracts on $\beta 2$ integrins (CD18) expression on PMNs and monocytes are shown in Table 4. The inhibition of CD18 expression by plant extracts and compounds was tested with the aid of flow cytometry. Except foe phyllanthin and hypophyllanthin, the plant extracts and pure compounds possessed weak inhibition of CD18 expression on human leukocytes. Phyllanthin and hypohyllanthin depicted significant inhibition at $50 \mu \mathrm{g} / \mathrm{mL}$ with percentage of CD18 expression of $67.17 \%$ and $61.56 \%$ for PMNs and monocytes, respectively. The expression of CD18containing integrins is essential for the normal functioning of neutrophil in vivo. It plays an important role of cytotoxic killing by $\mathrm{T}$ cells. On the other hand, the binding of human leukocyte integrins (CD11a/CD18, CD11b/ CD18 and CD11c/CD18) to lipopolysaccharide (LPS), a bacterial endotoxin, triggers deleterious systemic inflammatory responses when released into blood circulation, causing organ damage $[40,41]$. The suppression of LPS 
Table 3 Percentage of phagocytic activity (\%) of neutrophils and monocytes at various concentrations of Phyllanthus amarus and $P$. urinaria extracts and their major compounds (mean $\pm S E M, n=3$ )

\begin{tabular}{|c|c|c|c|c|c|c|c|c|}
\hline \multirow[t]{2}{*}{ Sample $(\mu \mathrm{g} / \mathrm{mL})$} & \multicolumn{4}{|c|}{ Neutrophils } & \multicolumn{4}{|c|}{ Monocytes } \\
\hline & 100 & 50 & 6.25 & 3.125 & 100 & 50 & 6.25 & 3.125 \\
\hline PA (Mal) & $75.60 \pm 1.82$ & & $88.20 \pm 1.17$ & & $53.70 \pm 0.15$ & & $65.68 \pm 0.15$ & \\
\hline PA (Ind) & $81.65 \pm 2.21$ & & $89.29 \pm 2.67$ & & $66.68 \pm 3.16$ & & $74.60 \pm 2.76$ & \\
\hline PU (Mal) & $78.13 \pm 2.07$ & & $89.60 \pm 0.98$ & & $59.08 \pm 1.66$ & & $68.80 \pm 1.66$ & \\
\hline PU (Ind) & $73.30 \pm 3.32$ & & $79.40 \pm 1.07$ & & $61.86 \pm 2.81$ & & $72.22 \pm 3.02$ & \\
\hline GA & $88.60 \pm 1.52$ & & $95.90 \pm 1.97$ & & $76.50 \pm 2.18$ & & $77.80 \pm 1.71$ & \\
\hline EA & $85.20 \pm 1.19$ & & $88.18 \pm 2.13$ & & $75.50 \pm 1.97$ & & $67.10 \pm 2.31$ & \\
\hline Ger & $76.00 \pm 3.05$ & & $80.80 \pm 1.06$ & & $76.08 \pm 3.16$ & & $84.90 \pm 0.91$ & \\
\hline Cor & $85.50 \pm 2.82$ & & $86.10 \pm 0.32$ & & $80.70 \pm 1.51$ & & $85.38 \pm 1.04$ & \\
\hline Phyll & & $14.20 \pm 1.08$ & & $34.91 \pm 0.09$ & & $27.10 \pm 0.55$ & & $52.10 \pm 0.68$ \\
\hline Hypophyll & & $49.11 \pm 1.04$ & & $80.50 \pm 0.87$ & & $64.6 \pm 0.51$ & & $67.0 \pm 1.07$ \\
\hline Positive control & $91.60 \pm 1.15$ & & & & $84.6 \pm 4.84$ & & & \\
\hline
\end{tabular}

See Table 2 for legends.

binding site on human leukocytes may reduce the progress of inflammatory processes by inhibiting the expression of these integrins.

\section{Chemiluminescence assay}

Preliminary screening of the plant extracts on whole blood showed that $P$. amarus and $P$. urinaria from Malaysia exhibited high inhibitory activity for luminol-enhanced chemiluminescence with $\mathrm{IC}_{50}$ values of 0.95 and $1.52 \mu \mathrm{g} / \mathrm{mL}$, respectively, for zymosan induced and 1.24 and $1.98 \mu \mathrm{g} / \mathrm{mL}$, respectively, for PMA induced (Table 2 and Figure 4). The Malaysian Phyllanthus samples were also more potent than the Indonesian samples against PMNs and monocytes. The extracts of $P$. amarus possessed higher inhibitory activity compared to $P$. urinaria. This might be associated with the presence of high amount of bioactive phenolic compounds in P. amarus compared to P. urinaria. Geraniin and corilagin exhibited $\mathrm{IC}_{50}$ values of 0.36 and $0.58 \mu \mathrm{M}$, respectively, in zymosan stimulated whole blood, and 0.21 and $0.35 \mu \mathrm{M}$, respectively, in PMA stimulated whole blood. Their $\mathrm{IC}_{50}$ values were lower than those of aspirin, indicating that they were more potent than the positive control. Aspirin was used as the positive control based on a previous report that the drug inhibited luminol-enhanced chemiluminescence of human leukocytes [42].

The extracts of Phyllanthus species and their major components were further investigated for their effects on the oxidative burst of PMA or zymosan stimulated PMNs and monocytes. The plant extracts from both

Table 4 Percentage of CD18 expression (\%) on neutrophils and monocytes at various concentrations of Phyllanthus extracts and their major compounds

\begin{tabular}{|c|c|c|c|c|c|c|c|c|}
\hline \multirow[t]{2}{*}{ Sample $(\mu \mathrm{g} / \mathrm{mL})$} & \multicolumn{4}{|c|}{ Neutrophils } & \multicolumn{4}{|c|}{ Monocytes } \\
\hline & 100 & 50 & 6.25 & 3.125 & 100 & 50 & 6.25 & 3.125 \\
\hline PA (Mal) & $79.62 \pm 1.82$ & & $87.10 \pm 1.23$ & & $70.79 \pm 2.13$ & & $85.68 \pm 1.10$ & \\
\hline PA (Ind) & $81.65 \pm 2.21$ & & $89.29 \pm 2.67$ & & $62.39 \pm 1.87$ & & $89.29 \pm 1.51$ & \\
\hline PU (Mal) & $82.90 \pm 1.08$ & & $90.62 \pm 1.80$ & & $76.20 \pm 1.54$ & & $88.98 \pm 2.76$ & \\
\hline PU (Ind) & $87.15 \pm 3.39$ & & $93.20 \pm 3.39$ & & $85.18 \pm 0.51$ & & $85.41 \pm 1.69$ & \\
\hline GA & $81.33 \pm 1.80$ & & $88.77 \pm 2.41$ & & $68.60 \pm 1.20$ & & $76.50 \pm 2.18$ & \\
\hline EA & $86.14 \pm 2.01$ & & $90.18 \pm 1.07$ & & $62.20 \pm 0.57$ & & $77.10 \pm 1.99$ & \\
\hline Ger & $89.40 \pm 1.21$ & & $93.10 \pm 1.23$ & & $82.90 \pm 1.71$ & & $88.40 \pm 1.75$ & \\
\hline Cor & $92.10 \pm 1.02$ & & $95.80 \pm 0.98$ & & $79.51 \pm 1.10$ & & $85.38 \pm 1.32$ & \\
\hline Phyll & & $67.17 \pm 1.34$ & & $79.20 \pm 2.92$ & & $61.56 \pm 0.98$ & & $72.21 \pm 1.26$ \\
\hline Hypophyll & & $74.70 \pm 0.09$ & & $80.90 \pm 1.65$ & & $74.42 \pm 0.77$ & & $75.15 \pm 1.48$ \\
\hline Positive control & $93.93 \pm 0.54$ & & & & $84.79 \pm 0.55$ & & & \\
\hline
\end{tabular}



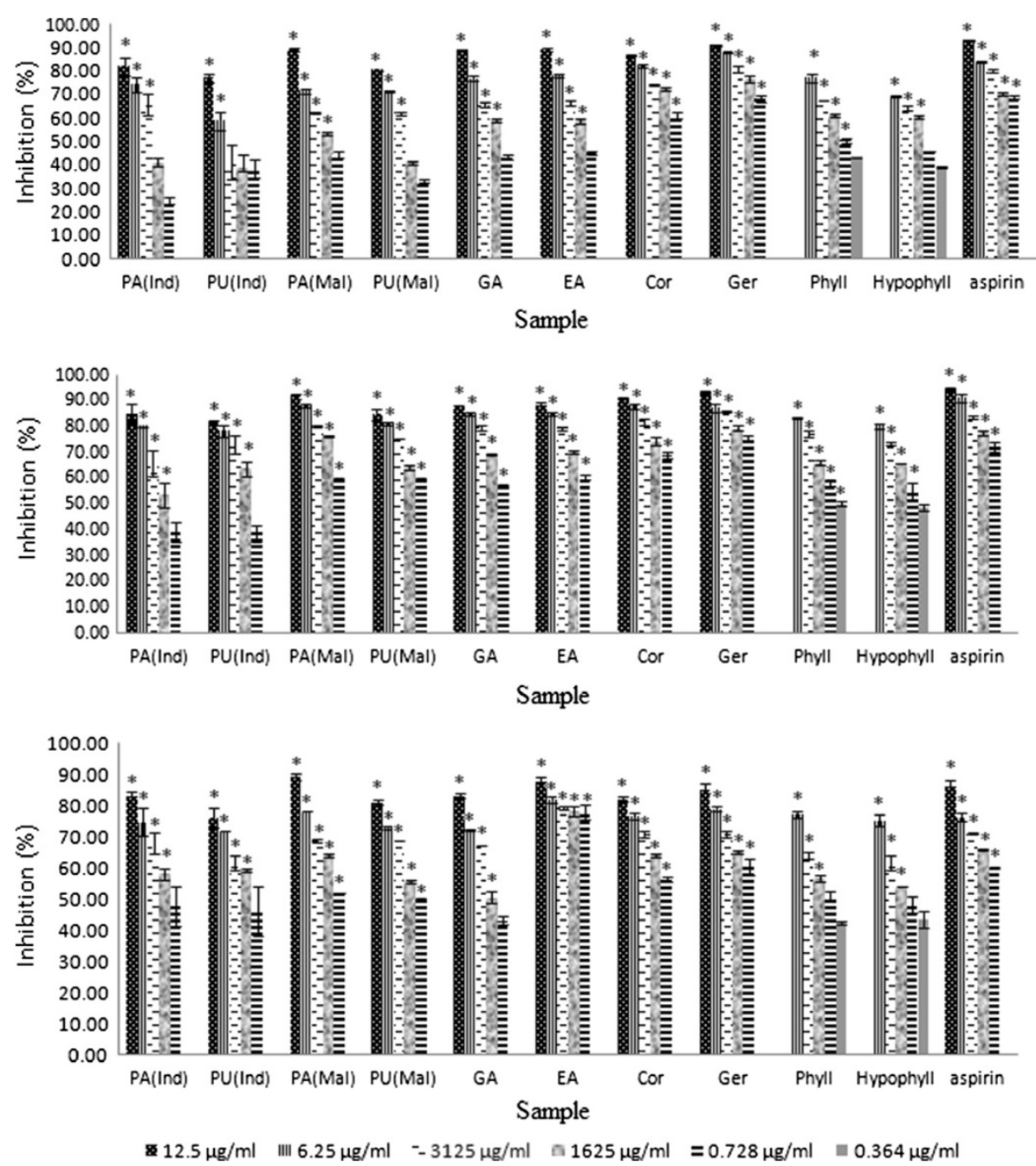

Figure 4 Percentage inhibition (\%) of ROS inhibitory activity of Phyllanthus sp. and their major compounds on PMA stimulated whole blood (a), PMNs (b) and MNCs (c) assayed by luminol amplified chemiluminescence. Data are mean $\pm \operatorname{SEM}(n=3)$. Significance of differences with respective control: ${ }^{*} P<0.05$. See Table 2 for legends.

countries and pure compounds showed significantly high inhibition of ROS production from zymosan and PMA stimulated leukocytes. Geraniin and corilagin exhibited exceptionally strong inhibition on ROS activity against PMNs and monocytes. The $\mathrm{IC}_{50}$ values of geraniin and corilagin were 0.18 and $0.56 \mu \mathrm{M}$, respectively, for zymosan induced and 0.13 and $0.24 \mu \mathrm{M}$, respectively for PMA induced PMNs. Their $\mathrm{IC}_{50}$ values were similarly much lower than those of aspirin against monocytes, indicating that they were more potent than the positive control. Figure 4 shows the percentage inhibition of oxidative burst of the Phyllanthus species and the pure compounds on PMA induced leukocytes, depicting a dose-dependent relationship.

It is increasingly proposed that ROS plays a key role in structural alteration of DNA, dysregulation of cytoplasmic and nuclear signal transduction and effect the activity of the proteins and genes that respond to stress and which act to regulate the genes that are related to cell proliferation, differentiation and apoptosis pathways. ROS is produced by phagocytes in response to a variety of stimulators for bacterial killing and amplification of inflammatory response. The NADPH oxidase complex plays essential role in ROS production. The activation of NADPH oxidase is induced by receptor ligation and engulfment of microbial pathogens, chemical or various stimuli, such as PMA, fMLP, or zymosan. In this study ROS generation was assessed upon stimuli with PMA which crosses the cellular membrane and binds to protein kinase $\mathrm{C}$ independent of cell receptor interaction and serum opsonized zymosan which stimulates neutrophils via their surface complement receptor (CR3) [43]. The present study indicates that similar inhibitory activity of ROS generation was noticed in phagocytes 
irrespective of the type of stimuli used. This clearly shows that $P$. amarus and $P$. urinaria have the capacity to inhibit ROS production through two different pathways.

Besides the defensive roles of phagocytes against infectious microbes, the phagocyte-microbe interactions between excessively or inappropriately deployed can damage host tissues and contribute to the pathogeny of various immune and nonimmune chronic inflammatory diseases. Therefore, the strong inhibition of the major compounds of $P$. amarus and P. urinaria on phagocytic activity of human phagocytes indicates that the extracts and their major constituents have the potential to be developed into agents for the treatment of a variety of disorders including inflammation.

\section{Conclusions}

The HPLC analysis methods proposed in this study enable identification and quantification of all major compounds found in the $80 \%$ ethanol extracts of $P$. amarus and $P$. urinaria. The HPLC quantification analysis indicated the presence of high amount of phenolic compounds in the plant extracts obtained from both Malaysia and Indonesia. The in vitro studies revealed that, the plant extracts, especially Malaysian P. amarus exhibited potent inhibitory activity of ROS generation and chemotactic activity of phagocytes stimulated by different stimuli. The results suggest that the immune regulatory action of the plant extracts act through various pathways. The phenolic compounds, geraniin, corilagin and ellagic acid demonstrated strong inhibition against the leukocytes. Geraniin and corilagin also exhibited exceptionally strong inhibition on ROS activity against PMNs for zymosan induced PMA induced leukocytes. In contrast, the phenolic compounds did not show significant effect on phagocytic activity and $\beta 2$ integrins expression of phagocytes. The inhibitory activity possessed by plant extracts at these steps could be due the contribution of phyllanthin and hypophyllanthin which exhibited potent inhibitory action on both phagocytic and CD18 expression of phagocytes. Thus, the in vitro study suggest that the presence of high levels of the major compounds of P.amarus and P.urinaria reported in this study could be the major contributors to the strong immunomodulatory effect of the plant.

\section{Competing interests}

The authors declare that they have no competing interests.

\section{Authors' contributions}

IJ participated in the design, and coordination of the study, analysis and interpretation of the data. He was also involved in drafting of the manuscript and gave the final approval of the version to be submitted for publication. $\mathrm{Ml}$ and $\mathrm{Y}$ carried out the experiments, analyzed the data and drafted the manuscript. HFM participated in collection of the plant samples and preparation of extracts. She was also involved in the quantitative determination of the major components of the plant extracts. All authors read and approved the final manuscript.

\section{Acknowledgement}

The work was supported by the Ministry of Agriculture Malaysia, under the NKEA Research Grant Scheme (NRGS) (Grant no. NH0811D003).

Received: 16 July 2014 Accepted: 15 October 2014

Published: 1 November 2014

\section{References}

1. Tak WM, Marry ES: The Immune Response Basic and Clinical Principles. Amsterdam: Elsevier Academic Press; 2006.

2. Holtzman MJ: Asthma as a chronic disease of the innate and adaptive immune systems responding to viruses and allergens. J Clin Invest 2005, 2005(122):2741-2748.

3. Beutler B: Innate immunity: an overview. J Mol Immunol 2004, 40:845-849.

4. Philippe G: Complement: a unique innate immune sensor for danger signals. J Mol Immunol 2004, 41:1089-1098.

5. Greenberg S, Greinstein S: Phagocytosis and innate immunity. Curr Opin in Immunol 2002, 14:136-145.

6. Snyderman R, Pike MC: Chemoattractant receptors on phagocytic cells. Annu Rev Immunol 1984, 2:257-281.

7. Snyderman R, Charles DS, Margrith WV: Model of leukocyte regulation by chemoattractants receptros: roles of guanine nucleotide regulatory protein and polyphosphoionotiside metabolism. J Leukocyte Biol 1986, 40:785-800

8. Stephens $L$, Ellson C, Hawkins P: Role of P13K in leukocyte chemotaxis and phagocytosis. Curr Opin in Cell Biol 2010, 14:203-213.

9. Coxon A, Rieu P, Askarib S, Sharpe AH, Adrian UH: A novel role for $\beta 2$ integrin CD11b/CD18 in neutrophil apoptosis: a homeostatic mechanism in inflammation. Immunity 1996, 5:653-666.

10. Nagahata $H$, Higuchi $H$, Yamashiki N, Yamaguchi M: Analysis of the fundamental characteristics of L-selectin and its expression on normal and CD18 deficient bovine neutrophils. Immunol Cell Biol 2000, 78:264-271.

11. Timothy $M C$, John MH: Leukocyte-endothelial adhesion molecule on blood lymphocytes, monocytes, and neutrophils. Blood 1994, 84:1201.

12. Ferrari R, Ceconi C, Curello S, Cargnoni A, Alfieri O: Oxygen free radicals and myocardial damage: protective role of thiolcontaining agents. Am J Med 1991, 91:95-105.

13. Mortensen RF, Zhong W: Regulation of phagocytic leukocyte activities by C-reactive protein. J Leukocyte Biol 2000, 67:495-500.

14. Liu Z, Mouming Z, Kegang W, Xianghua C, Hongpeng Y: Immunomodulatory and anti-cancer activities of phenolics from emblica fruit (Phyllanthus emblica L.). J Food Chem 2012, 131:685-690.

15. Haq A, Abdullah M, Lobo PI, Khabar KSA, Kirtikan VS: Nigella sativa: Effects on human lymphocytes and polymorphonuclear leukocytes phagocytic activity. J Immunopharmacol 1995, 30:147-155.

16. Nicholl DS, Daniels HM, Ira TM, Grayer RJ, Simmons MS: In vitro studies on immunomodulatory effects of Osbeckia aspera. J Ethnopharmacol 2001, 78:39-44.

17. Akbay $P$, Basaran $A A$, Undeger $U$, Basaran $\mathrm{N}$ : In vitro immunomodulatory activity of flavonoids glycosides from Urtica dioica L. Phytother Res 2003, 17:34-37.

18. Yu L, Zhao M, Yang B, Bai W: Immunomodulatory and anti-cancer activities of phenolics from Garcinia mangostana fruit pericarp. Food Chem 2009, 116:969-973.

19. Calixto JB, Santos AR, Cecinal Filho V, Yunes RA: A review of the plants of the genus Phyllanthus: Their chemistry, pharmacology, and therapeutic potential. Med Res Rev 1998, 18:225-258.

20. Wang M, Cheng H, Li Y, Meng L, Zhao G: Herbs of genus Phyllanthus in treatment of chronic Hepatitis B: Observation with three preparation from different geographic sites. J Lab Clin Med 1995, 126:350-352.

21. Joseph B, Raj SJ: An overview: pharmacognostic properties of Phyllanthus amarus Linn. Internat J Pharmacol 2011, 7:40-45.

22. Foo LY: Amarulone, a novel cyclic hydrolysable tannin from Phyllanthus amarus. Nat Prod Lett 1993, 3:45-52.

23. Chan HL, Sun JJ, Fon WF, Chim AML, Yung PP: Double-blinded placebo controlled study of Phyllanthus urinaria for treatment of chronic hepatitis. Ailment Pharmocol Ther 2003, 18:339-345. 
24. Fang SH, Rao YK, Tzeng YM: Anti-oxidant and inflammatory mediator's growth inhibitory effects of compounds isolated from Phyllanthus urinaria. J Ethnopharmacol 2008, 116:333-340.

25. Lin S-Y, Ching CW, Yeh LL, Wen CW, Wen CH: Anti-oxidant, anti-carbazide sensitive amine oxidase and anti-hypertensive activities of geraniin isolated from Phyllanthus urinaria. J Food Chem Toxicol 2008, 46:2485-2492.

26. Khan S, Al-Qurainy F, Ram M, Ahmad S, Abdin MZ: Phyllanthin biosynthesis in Phyllanthus amarus. Schum and Thonn growing at different altitudes. J Med Plants Res 2010, 4:1041-1048.

27. Chew FS, Rodman JE: Plant resources for chemical defense. In Herbivores: Their Interaction with Secondary Plant Metabolites. Edited by Rosenthal GA, Janzen DH. New York: Academic Press; 1979:271-307.

28. Yuandani A, Menaga I, Jantan I, Hazni F, Amirul F: Inhibitory effects of standardized extracts of Phyllanthus amarus and Phyllanthus urinaria and their marker compounds of phagocytic activity of human leukocyte. J Evid Based Complementary Altern Med 2013, doi:10.1155/eCAM.603634

29. Srividya N, Periwal S: Diuretic, hypotensive and hypoglycaemic effect of Phyllanthus amarus. Indian J Exp Biol 1995, 33:861-864.

30. Thyagarajan SP, Subramanian S, Thirunalasundari T, Venkateswaran PS, Blumberg BS: Effects of Phyllanthus amarus on the chronic carriers of hepatitis B virus. Lancet 1988, 2:764-766.

31. Oh H, Siano B, Diamond S: Neutrophil isolation protocol. J Vis Exp 2008 17:745.

32. Gmelig-Meyling F, Waldmann TA: Separation of human blood monocytes and lymphocytes on a continuous percoll gradient. J Immunol Meth 1980, 33:1-9.

33. Krifa M, Bouhlel I, Ghedira-Chekir L, Ghedira K: Immunomodulatory and cellular anti-oxidant activities of an aqueous extract of Limoniastrum guyonianum gall. J Ethnopharmacol 2013, 146:1243-249.

34. Jantan I, Hikmah HN, Wira SA, Murad S, Mesaik MA: Inhibition of chemiluminescence and chemotactic activity of phagocytes in vitro by the extracts of selected medicinal plants. J Nat Med 2011, 65:400-405.

35. Mazzone A, De Servi S, Ricevuti G, Mazzucchelli I: Increased expression of neutrophil and monocyte adhesion molecules in unstable coronary heart disease. J Circ 1993, 88:358-363.

36. Maderazo EG, Breaux SP, Woronick CL: Inhibition of human polymorphonuclear leukocyte cell responses by ibuprofen. J Pharm Sci 2006, 73:1403-1406.

37. Haqqi TM, Anthony DD, Gupta S, Ahmad N, Lee MS, Kumar GK, Mukhtar H: Prevention of collagen-induced arthritis in mice by a polyphenolic fraction from green tea. Proc Natl Acad Sci U S A 1999, 8:4524-4529.

38. Smedly LA, Tonnesen MG, Sandhaus RA, Haslett C, Guthrie LA: Neutrophil mediated injury to endothelial cells enhancement by endotoxin and essential roles of elastase. J Clin Invest 1986, 4:1233-1243.

39. Dale DC, Boxer L, Liles WC: The phagocytes: neutrophils and monocytes. J Blood 2008, 112:935-945

40. Werr J, Erikson EE, Per H, Lindbom L: Engagement of b2 integrins induces surface expression of b1 integrin receptors in human neutrophils. $J$ Leukoc Biol 2000, 68:553-560.

41. Weersink AJ, Van Kessel KP, Torensma R, Van Strijp JA, Verhoef J: Binding of rough lipopolysaccharides (LPS) to human leukocytes Inhibition by anti-LPS monoclonal antibody. J Immunol 1990, 1:318-324.

42. Abramson SB, Leszczynska-Piziak J, Clancy RM, Philips MR, Weissmann G: Inhibition of neutrophil function by aspirin-like drugs (NSAIDS): requirement for assembly of heterotrimeric $G$ proteins in bilayer phospholipid. Biochem Pharmacol 1994, 47:563-572.

43. Briggs RT, Robinson JM, Karnovsky ML, Karnovsky MJ: Superoxide production by polymorphonuclear leukocytes. J Histochem 1998, 84:371-376

doi:10.1186/1472-6882-14-429

Cite this article as: Jantan et al.: Correlation between the major components of Phyllanthus amarus and Phyllanthus urinaria and their inhibitory effects on phagocytic activity of human neutrophils. BMC Complementary and Alternative Medicine 2014 14:429. 